\title{
Evaluation of Surgical Techniques in Gynecomastia Treatment: Analysis of 65 Cases
}

\author{
Jinekomasti Tedavisinde Cerrahi Tekniklerin Değerlendirilmesi: 65 Olgunun Analizi
}

\author{
Muhammed Beşir ÖZTÜRK \\ (D) 0000-0002-8977-3741 \\ Cengiz ERTEKIN \\ (D) 0000-0003-4610-3219 \\ Tolga AKSAN \\ (D) 0000-0002-3328-2652 \\ Uğur Kaan KALEM \\ (1) 0000-0002-6291-3978 \\ Mustafa TEZCAN \\ (D) 0000-0002-3609-3312
}

Göztepe Training and Research Hospital Department of Plastic, Reconstructive and Aesthetic Surgery, Istanbul, Turkey

\section{Corresponding Author Sorumlu Yazar Cengiz ERTEKIN drcengizertekin@gmail.com}

Received / Gelis Tarihi : 29.01.2020 Accepted / Kabul Tarihi : 08.06.2020 Available Online /

Çevrimiçi Yayın Tarihi : 25.08.2020

\begin{abstract}
Aim: Gynecomastia is a benign enlargement of the breast in males. Surgical treatment options include liposuction, glandular excision and the combination of liposuction and glandular excision. In this study, it was aimed to evaluate 65 consecutive gynecomastia patients who were operated using different techniques and to present the treatment approach, and results and complications related to surgical techniques.

Material and Methods: Sixty five patients who underwent gynecomastia operation in our clinic between June 2016 and January 2019 were included in this study. Demographic data, preoperative and postoperative photographs, clinical classification, perioperative details, postoperative results and complications were evaluated retrospectively.

Results: Fifty five (84.6\%) patients had bilateral gynecomastia and $10(15.4 \%)$ patients had unilateral gynecomastia. Of the 120 breasts operated, 91 (75.8\%) were Grade II, 20 (16.7\%) were Grade III and $9(7.5 \%)$ were Grade I, according to the Simon classification. Twenty-eight $(43.1 \%)$ patients underwent liposuction and glandular excision, $35(53.8 \%)$ patients underwent liposuction alone, and two $(3.1 \%)$ patients underwent glandular excision only. Skin excision was performed for two patients at the first operation. Only two patients, one for inadequate reduction and the other for skin excess, were demanded revision surgery.

Conclusion: Surgical treatment options for gynecomastia patients can be determined according to clinical evaluation of breast tissue and skin excess. In young patients with good skin quality, skin excision can be left for a second session. Although there was no significant difference between the methods used in this study, more complications were found with the excisional technique.
\end{abstract}

Keywords: Gynecomastia; liposuction; surgery.

\section{ÖZ}

Amaç: Jinekomasti erkeklerde görülen iyi huylu meme büyümesidir. Cerrahi tedavi seçenekleri arasında liposakşın, glandüler eksizyon ve liposakşın ve glandüler eksizyon kombinasyonu yer almaktadır. Bu çalışmada farklı teknikler kullanılarak ameliyat edilen ardışık 65 jinekomasti hastasının değerlendirilmesi, tedavi yaklaşımının ve cerrahi tekniklerle ilgili sonuçların ve komplikasyonların sunulması amaçlanmıştır.

Gereç ve Yöntemler: Bu çalışmaya Haziran 2016 ve Ocak 2019 arasında kliniğimizde jinekomasti ameliyatı yapılan 65 hasta dahil edildi. Demografik veriler, preoperatif ve postoperatif fotoğraflar, klinik sınıflandırma, perioperatif detaylar, postoperatif sonuçlar ve komplikasyonlar retrospektif olarak değerlendirildi.

Bulgular: Elli beş $(\% 84,6)$ hastada iki taraflı jinekomasti ve 10 hastada $(\% 15,3)$ tek taraflı jinekomasti vardı. Simon sinıflamasına göre, ameliyat edilen toplam 120 memenin 91 $(\% 75,8)$ 'i Evre II, $20(\% 16,7)$ 'si Evre III ve $9(\% 7,5)$ 'u Evre I idi. Yirmi sekiz $(\% 43,1)$ hastaya liposakşıı ve glandüler eksizyon uyguland1, $35(\% 53,8)$ hastaya sadece liposakşın yapıldı ve $2(\% 3,1)$ hastaya sadece glandüler eksizyon uygulandı. İlk ameliyatta iki hastaya deri eksizyonu yapıldı. Biri yetersiz küçültme ve diğeri ciltte fazlalığı için olmak üzere sadece iki hasta revizyon cerrahisi talep etti.

Sonuç: Jinekomasti hastalarında meme dokusunun klinik değerlendirilmesine ve cilt fazlalığı derecesine göre cerrahi tedavi seçeneği belirlenebilir. Genç hastalarda deri kalitesi iyi ise cilt fazlalığı olsa dahi cilt ekzisyonu ikinci bir seansa bırakılabilir. Bu çalışmada kullanılan yöntemler arasında anlamlı bir fark olmamasına rağmen, eksizyonel teknikte daha fazla sayıda komplikasyon görülmüştür.

Anahtar kelimeler: Jinekomasti; liposakşın; cerrahi. 


\section{INTRODUCTION}

Gynecomastia is the benign growth of glandular breast tissue and skin in men (1). Its global prevalence ranges from $32 \%$ to $65 \%$ (2). The course of the disease is associated with unsatisfactory body perception as well as severe anxiety, stress and reduced quality of life (3). Although it is often idiopathic, it can be secondary to various metabolic and endocrine diseases, such as alcoholic cirrhosis, hypogonadism, adrenal cortex hyperplasia and hypothyroidism, drugs and acquired or congenital hypogonadal conditions, including Klinefelter syndrome (4). Histologically, it is classified as fluoride, fibrous and intermediate forms (5). Clinically, gynecomastia forms have been defined as glandular, fatty and composite (fatty-glandular). Simon grading is one of the mostly used classification systems for gynecomastia patients. Grade I includes patients with mild enlargement with no skin excess, Grade II, moderate enlargement with or without skin excess, Grade III marked enlargement with skin excess (4). Treatment is determined according to excess skin and clinical classification of gynecomastia (6). Treatment options include follow-up, medical treatment and surgical intervention (7). Surgical intervention is the gold standard in primary idiopathic gynecomastia (8). In recent years, surgical treatment has shown significant changes from the open approach towards liposuction assisted therapies and the use of open approach without liposuction is reserved only for limited cases $(9,10)$.

This study was aimed to investigate the patients who underwent surgical treatment in the form of glandular excision, liposuction plus glandular excision or liposuction only.

\section{MATERIAL AND METHODS}

This study included 65 patients who underwent gynecomastia surgery in our clinic between June 2016 and January 2019. The study was approved by the Istanbul Medeniyet University Göztepe Training and Research Hospital Clinical Research Ethical Committee with the number of 2020/0239. Demographic data, imaging studies, preoperative and postoperative photographs, grading data (Simon Classification), ultrasonography results, clinical classification, comorbidities, postoperative results and complications were collected retrospectively.

\section{Surgical Technique}

Preoperative drawings were made while the patients were standing. All operations were performed under general anaesthesia. A solution with a 1/500000 concentration of epinephrine-containing Ringer's lactate was used as a tumescent solution. It was applied to the lateral side of the infra-mamarian fold using $0.4 \mathrm{~cm}$ incisions made at the level of the anterior axillary line. In cases requiring an additional incision, a second incision was made on the midclavicular line on the infra-mamarian fold. Liposuction performed in radial pattern, first in deep fatty plane, subsequently in superficial fat. Three holed liposuction cannulas with the diameter of $3 \mathrm{~mm}$ and $4 \mathrm{~mm}$ were used. Patients were evaluated for glandular and skin excision after liposuction. If glandular excision was planned, a 2-4 $\mathrm{cm}$ incision was made in the inferior semi-areolar region. Areola was elevated as a superior-based flap with a minimum thickness of $0.5 \mathrm{~cm}$. Anterior attachments of glandular tissue were cut, subsequently posterior attachments were incised over pectoral fascia from inferior to superior to excise glandular tissue. Hemovac drains were used in patients who underwent excision. The drains were inserted from the lateral incision which is used for liposuction and kept for 24-48 hours. Compression corset were recommended for the first month after the operation. The heavy activity was restricted for 1.5 months.

\section{RESULTS}

Sixty five patients included in the study, of which 55 $(84.6 \%)$ had bilateral gynecomastia, and 10 (15.4\%) had unilateral gynecomastia. Our patients' ages ranged from 13 to 67 (mean of 25) years. A total of 120 breasts were classified according to Simon classification; 91 (75.8\%) breasts were at Grade II, $20(16.7 \%)$ breasts were at Grade III and $9(7.5 \%)$ breasts at Grade I (Table 1). Twenty six $(40.0 \%)$ of the patients had fatty pattern breasts, 19 (29.2\%) of the patients had a glandular type and 20 $(30.8 \%)$ of them had a mixed pattern. The clinical examinations were consistent with the ultrasonography examinations. Twenty-eight $(43.1 \%)$ patients underwent liposuction and glandular excision, $35(53.8 \%)$ patients underwent liposuction alone and 2 (3.1\%) patients underwent glandular excision only (Figure 1). 33.3\% $(n=15)$ of Grade IIa and $37.0 \%(n=17)$ of Grade IIb and $50.0 \%(n=10)$ of Grade III breasts were treated using both liposuction and glandular excision (Figure 2). Liposuction was performed alone on $66.7 \%(n=6)$ of Simon Grade I breasts, this percentage was $66.7 \%(\mathrm{n}=30)$ in Grade IIa, $63.0 \%(n=29)$ in Grade IIb and $50.0 \%(n=10)$ in Grade III breasts (Figure 3). Two breasts were successfully treated

Table 1. Gynecomastia grades of patients and surgical techniques in each grade ( $\mathrm{n}=120$ breast)

\begin{tabular}{lcccc}
\hline & $\begin{array}{c}\text { Grade I } \\
(\mathbf{n}=\mathbf{9})\end{array}$ & $\begin{array}{c}\text { Grade IIa } \\
(\mathbf{n = 4 5})\end{array}$ & $\begin{array}{c}\text { Grade IIb } \\
(\mathbf{n}=\mathbf{4 6})\end{array}$ & $\begin{array}{c}\text { Grade III } \\
(\mathbf{n = 2 0})\end{array}$ \\
\hline $\begin{array}{l}\text { Liposuction } \\
\text { Glandular }\end{array}$ & $6(66.7)$ & $30(66.7)$ & $29(63.0)$ & $10(50.0)$ \\
$\begin{array}{l}\text { Excision } \\
\text { Liposuction }+\end{array}$ & $2(22.2)$ & $0(0.0)$ & $0(0.0)$ & $0(0.0)$ \\
$\begin{array}{l}\text { Glandular } \\
\text { Excision }\end{array}$ & $1(11.1)$ & $15(33.3)$ & $17(37.0)$ & $10(50.0)$ \\
\hline
\end{tabular}

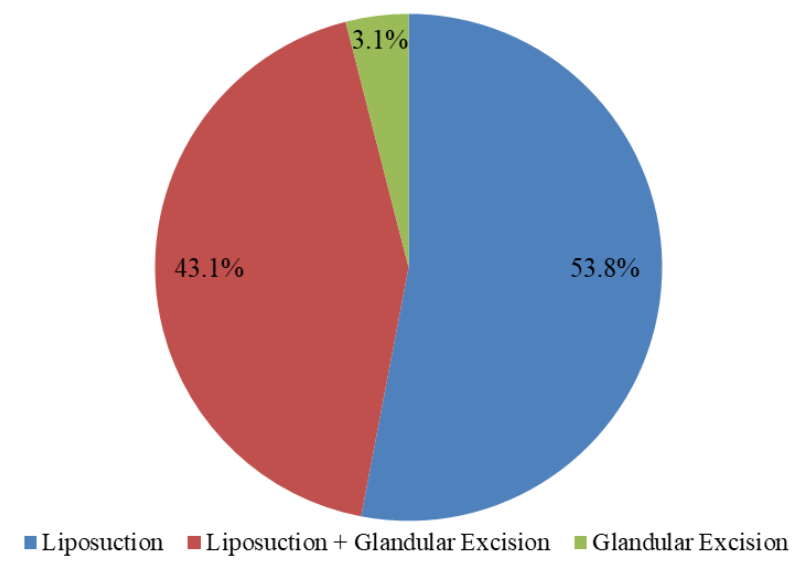

Figure 1. The rate of surgical techniques ( $n=65$ patient) 

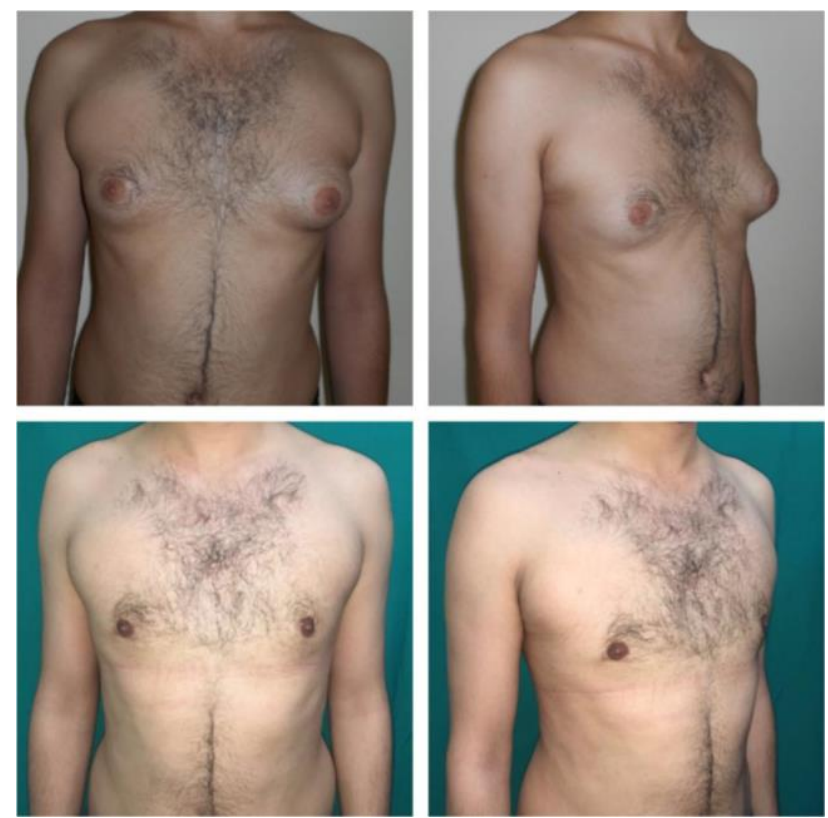

Figure 2. Bilateral Simon Grade IIa gynecomastia, liposuction and glandular excision, preoperative and nine months after surgery, $300 \mathrm{cc}$ lipoaspirate for each breast

with glandular excision only, these 2 patients were in Grade I group. A 13-year-old patient who presented with severe gynecomastia, underwent reduction mammoplasty surgery for excess skin removal. In that case bilateral nipple jugulum distances were $29 \mathrm{~cm}$. Another case that we had excised skin was a 40 years old post-bariatric patient. Five patients underwent additional circumferential areola reduction during surgery. The mean surgical time was 100 (range, 45-185) min. The mean follow-up period was 20 months.

The pathologic examination was performed for glandular excision group. There were no findings other than fibrous gynecomastia. Unilateral gynecomastia patients were examined separately by the means of pathology results and additional diseases. There were no additional pathology finding except from fibrous gynecomastia in their specimens. One patient had history of cryptorchidism and another patient had history of prolactinoma. Preoperative routine ultrasonography was obtained from all the patients in this study and ultrasonography examinations of the breasts did not reveal any pathological masses. We have performed skin excision in two patients at the first session of the operation. There was only one patient in Grade III who requested reoperation in long term follow-up. Among all groups, there was no other patient that required a second intervention for skin removal.

We have compared the mean volume of lipoaspirate in all patients. We have found that the volume increased proportionally with Simon grades. The mean volume values of lipoaspirate were $221.4 \mathrm{ml}$ (Grade I), $305.2 \mathrm{ml}$ (Grade II), and $391.2 \mathrm{ml}$ (Grade III) in order.

A hematoma developed in one patient with glandular excision group in the early postoperative period. The patient was re-operated at the same day and bleeding control was achieved. There were no postoperative seroma cases in patient groups. None of the patients developed an infection, areola necrosis or nipple retraction. The inadequate
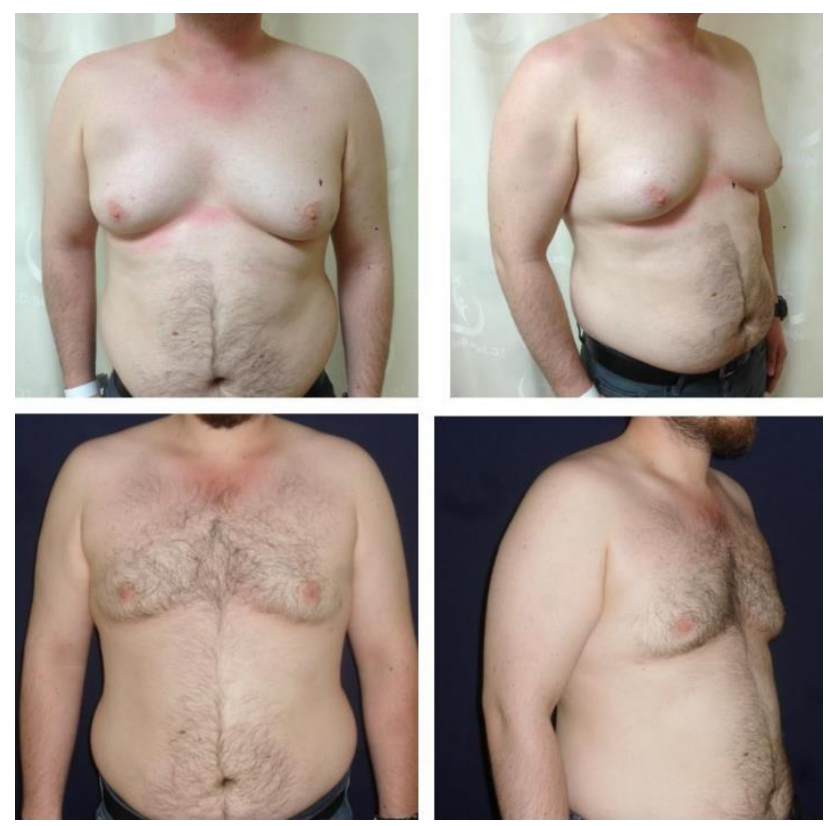

Figure 3. Bilateral Simon Grade IIb gynecomastia, bilateral liposuction only, preoperative and five months after surgery, $400 \mathrm{cc}$ lipoaspirate for each breast

reduction occurred in five patients. Only one of the patients with inadequate reduction requested re-operation. Two patients required debridement and scar revision in early postoperative period due to thermal burns at cannula access areas.

\section{DISCUSSION}

Although gynecomastia may occur for physiological, pathological and pharmacological reasons, the majority of cases are idiopathic (11). Pathophysiological studies state that the disease is caused by an imbalance of the hormones synthesized in the zona reticularis of the adrenocortical gland (12). Increased levels of oestrogen or deficiency of testosterone cause breast tissue growth in men (1). Obesity contributes to the process by increasing the oestrogen level proportional to fatty tissue (13). Feminine-looking breast tissue can cause serious psychosocial stress in men, and this is the main factor leading the patient to seek a surgical procedure (2).

Surgical options include nipple-sparing subcutaneous mastectomy, liposuction and combinations of these two options (14). The surgical approach is superior to medical treatment because it is faster and more effective with better aesthetic results and less recurrence (1).

In the last 20 years, the open technique has been abandoned, and the trend towards minimally invasive techniques has increased (15). The current literature supports ultrasound-assisted liposuction (UAL) alone or a combination of liposuction with glandular excision using periareolar incision and the pull-through technique (7). The type of surgery is decided based on clinical and ultrasonographic examination of the breasts. Periareolar glandular excision is mostly combined with liposuction in glandular and composite pattern breasts whereas in fatty breasts mostly liposuction was performed alone (4).

Except for two cases, conventional vacuum-assisted liposuction (VAL) before glandular excision was used for all 
of the patients in this study. In previous studies, it was reported that UAL produced more effective fat emulsification than VAL and is more effective in dense fibroconnective tissue areas (14). Although conventional and ultrasonic liposuction was not compared in this retrospective study, in patients with the minimal glandular component, sufficient results were achieved with the only VAL.

Rochrich et al. (6) used UAL only in $85 \%$ of their patients and reported good results without performing additional incisions or resections. They recommended re-evaluating patients for skin redraping about six months after UAL. Although we used classical liposuction in all cases, satisfactory results were also achieved in Grade IIb and Grade III patients without skin excisions. Among Grade IIb, $29(63.0 \%)$ patients were treated with liposuction only and $17(37.0 \%)$ patients were treated with liposuction and glandular excision. In Grade III, $50.0 \%(n=10)$ of patients were treated with liposuction and in other half combined technique was used. Patients were followed for six months for skin redraping after liposuction, and only one patient in the Grade III group had required reoperation for skin excess, an inverted $\mathrm{T}$ pattern skin excision was used in this case. Generally, mean age of the patients requiring gynecomastia surgery is low. In young patients, skin redraping is usually sufficient after liposuction and skin excisions can be planned later if needed. One of the patients that we performed skin removal in first operation was a postbariatric patient who had poor skin quality and elasticity. The other patient had severe skin excess and his nipple-jugulum distances were $29 \mathrm{~cm}$ bilaterally.

Fodor et al. (16) and Scuderi et al. (17) compared powerassisted liposuction (PAL) with traditional liposuction. They concluded that the use of PAL provided faster fat aspiration and caused less fatigue. In the present study, the mean surgical time was 100 minutes. A review of the literature found that shorter operative times were reported in similar studies (18). We believe that the use of conventional liposuction in our cases contributed to this outcome.

Petty et al. (15) compared four groups of gynecomastia patients using liposuction, excision, combined methods and arthroscopic shavers. They reported that they did not detect a significant difference between the groups in terms of complications. In their study, seromas were the most common complication in all groups. Courtiss et al. (9) reported a higher rate of complications $(18.7 \%)$ in their study that covered 156 patients treated with the excisional technique, and the most common complications were reported as over/under resection and hematoma. In the present study, the inadequate reduction was determined in five patients, and hematoma developed in three patients. In this study, none of the patients developed areolar necrosis or seroma that requires intervention. When surgical techniques were compared in different groups (excisional, combined and liposuction alone), no significant differences in terms of complications were found.

Lista et al. (19) reported that they achieved satisfactory results in 96 patients with combined liposuction and pullthrough glandular excision techniques. They reported that only two patients developed seromas in the postoperative period. Hammond et al. (20) reported satisfactory results in their study covering 15 patients in which they used UAL with the pull-through technique. In their study, Bracaglia et al. (21) used pull through technique with liposuction on 45 patients and reported good results. Hematoma occurred in one patient, and inadequate reduction occurred in one patient.

In the present study, the pull-through technique was used in seven patients. No additional complications occurred, and no re-operations were required.

The main limitation of our study was the inadequate sample of patients in glandular excision group. Also, we have not weighed the glandular excision materials in our patients so this may cause difficulty when comparing with other studies.

\section{CONCLUSION}

Gynecomastia is the persistent enlargement of breast tissue in men, and surgical treatment is the most effective option. Surgical options can be classified as liposuction, excision and combined techniques. Surgical treatment options can be determined according to clinical evaluation of breast tissue and skin excess. In young patients with good skin quality, skin excision may be left for a second session. Although there was no significant difference between the methods used in this study, more complications were found with the excisional technique.

\section{REFERENCES}

1. Zavlin D, Jubbal KT, Friedman JD, Echo A. Complications and outcomes after gynecomastia surgery: Analysis of 204 pediatric and 1583 adult cases from a National Multi-center Database. Aesthetic Plast Surg. 2017;41(4):761-7.

2. Ridha H, Colville RJI, Vesely MJJ. How happy are patients with their gynaecomastia reduction surgery. J Plast Reconstr Aesthet Surg. 2009;62(11):1473-8.

3. Kinsella C Jr, Landfair A, Rottgers SA, Cray JJ, Weidman C, Deleyiannis FWB, et al The psychological burden of idiopathic adolescent gynecomastia. Plast Reconstr Surg. 2012;129(1):1-7.

4. Innocenti A, Melita D, Francesco M, Francesco C, Innocenti M. Management of gynecomastia in patients with different body types: Considerations on 312 consecutive treated cases. Ann Plast Surg. 2017;78(5):492-6.

5. Bannayan GA, Hajdu SI. Gynecomastia: Clinicopathologic study of 351 cases. Am J Clin Pathol. 1972;57(4):431-7.

6. Rohrich RJ, Ha RY, Kenkel JM, Adams WP Jr. Classification and management of gynecomastia: Defining the role of ultrasound-assisted liposuction. Plast Reconstr Surg. 2003;111(2):909-23.

7. Cuhaci N, Polat SB, Evranos B, Ersoy R, Cakir B. Gynecomastia: clinical evaluation and management. Indian J Endocrinol Metab. 2016;18(2):150-8.

8. Prezioso D, Piccirillo G, Galasso R, Altieri V, Mirone V, Lotti T. Gynecomastia due to hormone therapy for advanced prostate cancer: A report of ten surgically treated cases and a review of treatment options. Tumori. 2004;90(4):410-5.

9. Courtiss EH. Gynecomastia: Analysis of 159 patients and current recommendations for treatment. Plast Reconstr Surg. 1987;79(5):740-53.

10. Hodgson ELB, Fruhstorfer BH, Malata CM. Ultrasonic liposuction in the treatment of gynecomastia. Plast 
Reconstr Surg. 2005;116(2):646-53.

11. Asfuroğlu Barutca S, Kutlu N, Uscetin I, Egemen O, Aksan T, Askeroglu U. Gynecomastia treatment principles: Evaluation of our results. Eur Arc Med Res. 2011;27(1):36-43.

12. Ersoz H, Onde ME, Terekeci H, Kurtoglu S, Tor H. Causes of gynaecomastia in young adult males and factors associated with idiopathic gynaecomastia. Int $\mathbf{J}$ Androl. 2002;25(5):312-6.

13. Johnson RE, Murad MH. Gynecomastia: pathophysiology, evaluation, and management. Mayo Clin Proc. 2009;84(11):1010-5.

14. Boljanovic S, Axelsson CK, Elberg JJ. Surgical treatment of gynecomastia: liposuction combined with subcutaneous mastectomy. Scand J Surg. 2003;92(2):160-2.

15. Petty PM, Solomon M, Buchel EW, Tran NV. Gynecomastia: Evolving paradigm of management and comparison of techniques. Plast Reconstr Surg. 2010;125(5):1301-8.

16. Fodor PB, Vogt PA. Power-assisted lipoplasty (PAL): A clinical pilot study comparing PAL to traditional lipoplasty (TL). Aesthetic Plast Surg. 1999;23(6):37985.

17. Scuderi N, Paolini G, Grippaudo FR, Tenna S. Comparative evaluation of traditional, ultrasonic, and pneumatic assisted lipoplasty: Analysis of local and systemic effects, efficacy, and costs of these methods. Aesthetic Plast Surg. 2000;24(6):395-400.

18. Braunstein GD. Gynecomastia. N Engl J Med 1993;328(7):490-5.

19. Lista F, Ahmad J. Power-assisted liposuction and the pull-through technique for the treatment of gynecomastia. Plast Reconstr Surg. 2008;121(3):7407.

20. Hammond DC, Arnold JF, Simon AM, Capraro PA. Combined use of ultrasonic liposuction with the pullthrough technique for the treatment of gynecomastia. Plast Reconstr Surg. 2003;112(3):891-7.

21. Bracaglia R, Fortunato R, Gentileschi S, Seccia A, Farallo E. Our experience with the so-called pullthrough technique combined with liposuction for management of gynecomastia. Ann Plast Surg. 2004;53(1):22-6. 